\title{
Trophic interactions in Zostera marina beds along the Swedish coast
}

\author{
Therese Jephson ${ }^{1, *}$, Per Nyström ${ }^{2}$, Per-Olav Moksnes ${ }^{3}$, Susanne P. Baden ${ }^{4}$ \\ ${ }^{1}$ Department of Ecology, Marine Biology, Campus Helsingborg, Lund University, Box 882, 25108 Helsingborg, Sweden \\ ${ }^{2}$ Department of Ecology, Limnology, Ecology Building, Lund University, 22362 Lund, Sweden \\ ${ }^{3}$ Department of Marine Ecology, University of Gothenburg, Box 461, 40530 Göteborg, Sweden \\ ${ }^{4}$ Department of Marine Ecology, University of Gothenburg, The Sven Loven Centre for Marine Sciences - Kristineberg, \\ 45034 Fiskebäckskil, Sweden
}

\begin{abstract}
We compared eelgrass Zostera marina communities in 3 regions in Sweden believed to be affected by eutrophication and overfishing, to determine whether bottom-up or top-down processes control the biomass of epiphytic macroalgae and grazers. Nitrogen and carbon isotope signatures were analyzed to explore the food webs and to identify the grazing species feeding on filamentous algae and/or eelgrass. Mixing model (IsoSource version 1.3.1) analysis of the isotope signatures indicated that the amphipods Gammarus locusta and Microdeutopus gryllotalpa fed primarily on filamentous algae and that only 2 small gastropod species consumed eelgrass. Moreover, the grass shrimp Palaemon elegans and $P$. adspersus were ca. 1 trophic level above amphipods and algae, but according to the mixing model played different trophic roles in the different areas. The highest biomass of filamentous algae was found in the west coast beds housing grazers with the lowest biomass and mean size (predominantly G. locusta and M. gryllotalpa, 0.5 to $3 \mathrm{~mm}$ ). In contrast, the Baltic Sea beds had low algal biomass, but the grazers (mostly G. locusta and Idotea baltica) had higher biomass and were significantly larger (mean size ca. $10 \mathrm{~mm}$ ). An overall negative correlation was found between grazer biomass and biomass of filamentous algae. The significantly smaller grazers and absence of isopod grazers on the west coast may be due to substantial consumption by small predatory fish. This supports the suggestions that, in Swedish eelgrass beds, grazers are top-down controlled, and overexploitation of large predators and eutrophication play an important role in the recent increases in algal biomass.
\end{abstract}

KEY WORDS: Seagrass $\cdot$ Eelgrass $\cdot$ Zostera $\cdot$ Stable isotopes $\cdot$ Mixing model $\cdot$ Trophic interactions Resale or republication not permitted without written consent of the publisher

\section{INTRODUCTION}

The most serious and widespread anthropogenic disturbances in coastal ecosystems include eutrophication (Short \& Wyllie-Echeverria 1996, Howarth et al. 2000) and overfishing (Jackson et al. 2001, Myers \& Worm 2003). Eutrophication is considered to be one of the main reasons for loss of seagrass (see reviews by Hauxwell et al. 2003, Hughes et al. 2004), because an increased nutrient supply enhances phytoplankton production and turbidity and also promotes the annual rapid growth of filamentous algae and epiphytic and free-floating macroalgal mats, which in turn reduce the supply of light and nutrients to the seagrass
(Duarte 1995, Valiela et al. 1997). However, reviews by Hughes et al. (2004) and Valentine \& Duffy (2005) have shown that an increased nutrient load alone often has little negative effect on seagrass growth, as long as natural populations of mesograzers (i.e. amphipods, isopods, and gastropods) are present to harvest the algae.

In addition to the effect of increased nutrient load, overfishing may indirectly influence seagrass growth via a trophic cascade (Heck et al. 2000). When top predators are removed from the system, there may be an increase in the number of smaller primary predators, mainly fish, which might reduce the abundance of small invertebrate algal grazers and thereby allow a 
rise in epiphyte biomass (Heck et al. 2000, Valentine \& Heck 2001). Hence, both eutrophication and overfishing may have a pronounced impact on the growth of seagrass by affecting epiphytes through a combination of top-down and bottom-up processes. Moreover, species-specific differences in the diets of grazers can give rise to significant variation in epiphyte biomass (Duffy \& Harvilicz 2001). In particular, key invertebrate grazers can consume both epiphytes and seagrass, and thus their effects on seagrass can be either positive or negative, depending on the availability of alternative food (Hughes et al. 2004, Valentine \& Duffy 2005).

The aim of the present study was to assess differences in beds of eelgrass Zostera marina (hereafter simply Zostera) growing along the west, south, and southeast coasts of Sweden by studying variation in the biomasses of eelgrass, ephemeral algae, and grazers from a top-down versus a bottom-up perspective. In short, we compared 2 opposing hypotheses: (1) that eelgrass systems are generally bottom-up controlled, and therefore those with the highest production and biomass of ephemeral and epiphytic macroalgae will contain the largest mesograzer biomass and (2) that such systems are usually top-down controlled, and thus those with the lowest mesograzer biomass will have the highest algal biomass. We performed stable isotope analyses of nitrogen and carbon to investigate the trophic interactions in each of the hypothetical systems, especially to identify the diets of important mesograzers and their predators and to determine whether any of the species consume eelgrass.

Zostera is the most common seagrass along the coast of Sweden, and it provides a physical habitat, food, and predation refuge for a variety of organisms, including several commercial species (Baden \& Pihl 1984, Orth \& Van Montfrans 1984, Baden 1990, Polte et al. 2005). It has been found that Zostera beds off the west, south, and southeast coasts differ with regard to how they are affected by eutrophication and the abundance of predators. Since the 1980 s, $58 \%$ of the eelgrass beds along the west coast have been lost (Baden et al. 2003), which can be compared with the fact that the nutrient load to Swedish coastal systems has been increasing since the 1930s (Rosenberg et al. 1990). In addition, mats of filamentous algae dominated by species of the genus Ulva (syn. Enteromorpha) have increased (Pihl et al. 1999), and abundance of the commercially important cod Gadus morhua has decreased dramatically (Svedäng 2003, Svedäng \& Bardon 2003).

Zostera beds in the Baltic Sea of the south and southeast coasts of Sweden have also been affected by the growing nutrient load over the last century, and the winter concentrations of $\mathrm{PO}_{4}$ in that area are similar to those seen off the west coast, whereas the levels of $\mathrm{NO}_{3}$ are about 3 times lower (Rosenberg et al. 1990,
Lundgren 2004, Andersson \& Andersson 2006). However, in contrast to the west coast, there is no indication that the distribution of the Baltic eelgrass beds has decreased in recent years. On the south coast, monitoring results show that there has been an increase in Zostera shoot density and biomass over the last $10 \mathrm{yr}$ (Lundgren et al. 2006). Filamentous algae have not been observed in large amounts in Zostera beds in the Baltic, whereas they are frequently abundant in shallower areas (Norkko \& Bonsdorff 1996, Lundgren et al. 2006). The overfishing of the Baltic stock of cod is alarming, but there is a stable population of that species in Öresund close to our south coast sampling site, where individuals $>30 \mathrm{~cm}$ in length are common (Lagenfelt \& Svedäng 1999). In addition, there are reports indicating several years of recruitment failure for both small and large predatory fish (e.g. perch Perca fluviatilis, pike Esox lucius, and roach Rutilus rutilus) in the area of our southeast location, which indicates extremely low abundances (Andersson et al. 2000, Nilsson et al. 2004). Thus it seems that the abundance of fish differs between Zostera beds in the west, south, and southeast coastal waters of Sweden, although at present there are no quantitative data available that can show the occurrence of large individual fish in the separate beds. Nevertheless, the indications of disparities between the areas with regard to the abundance of different fish species and epiphytic algae can allow interesting comparisons of potential top-down and bottom-up effects in Swedish eelgrass beds. Little is currently known about the biomass and composition of ephemeral algae and grazers in the Zostera beds of the Swedish south and southeast coasts, and indeed there are no data that have identified the species that graze on Zostera in Swedish waters.

\section{MATERIALS AND METHODS}

The investigation was carried out in 5 Zostera beds in 3 different regions: the west coast ( 2 sites in Gullmar Fjord), the south coast (1 site at Fredshög), and the southeast coast (2 sites in Kalmar Sound in the Baltic Sea) (Fig. 1). The sampling at all 5 sites was carried out between 26 August and 7 September 2004 during the period of peak Zostera biomass on the west coast (Baden \& Pihl 1984). The 2 west coast Zostera beds are located in sheltered bays with soft sediment (mainly clay) on the eastern side of Gåsö Island (Site 1) and on the western side of Lindholmen Island (Site 2). The south coast site (Site 3 ) is in a more exposed location with sandy sediment, and there is one continuous Zostera bed along the shore. In the southeast coastal region, we studied an eelgrass bed growing on sandy 
sediment in an exposed location near Saxnäs (Site 4) and another bed at Beijershamn that was in a more sheltered area with a clay sediment (Site 5). Salinity varied from $6 \%$ on the southeast coast to ca. $20 \%$ on the west coast (see Table 1 for details of the study sites).

Field sampling and analysis. Zostera was sampled by a SCUBA diver using a trap designed as a bag (mesh size $0.2 \mathrm{~mm}$, height $1.0 \mathrm{~m}$ ) with a quadratic steel frame measuring $0.12 \mathrm{~m}^{2}(0.35 \times 0.35 \mathrm{~m})$ in the opening. The trap was carefully lowered over the Zostera, and the shoots were cut at the bottom. Six samples were taken randomly in each bed, and they were immediately put on ice and later frozen before analysis in the laboratory. For analysis of Zostera biomass, leaf length, and shoot density, 5 to 6 additional samples were taken using steel rings with an area of $0.1 \mathrm{~m}^{2}$ that were placed randomly in the bed, and the shoots were cut at the bottom. Temperature and salinity were noted. To obtain an estimate of the organic content of the sediment, 3 to 5 samples of the upper $5 \mathrm{~cm}$ of sediment were randomly collected within the Zostera beds at each site by use of a corer (diameter $4.5 \mathrm{~cm}$ ). The organic content was measured as loss on ignition (LOI) by calculating the difference in weight before and after heating at $450^{\circ} \mathrm{C}$ for $3 \mathrm{~h}$. LOI was measured to allow comparison of our data with the findings of Baden \& Pihl (1984) in the 1980s.

To determine the biomass of algae in the Zostera beds, loose parts of filamentous free-floating macroalgae were selected, and the epiphytes were scraped from the top $20 \mathrm{~cm}$ of the leaves from 20 randomly chosen Zostera shoots (minimal fouling is found below that point). Epiphytic and free-floating macroalgae were separately dried at $60^{\circ} \mathrm{C}$ for $24 \mathrm{~h}$ to estimate dry weight (DW). In the samples from the west coast sites, the leaves were coated with a mixture of short epiphyte filaments, amphipod tubes, and detritus. The biomass of the epiphytic algae was calculated by estimating the volume percentage of algal species in the mixture and weighing to determine the total amount of fouling (excluding epifauna). In the samples from the sites in the other 2 regions, the Zostera leaves bore mainly epiphytic microalgae, which were collected by scraping the leaves in a bowl of seawater and subsequently pouring the water through a GF/F glass fiber filter (0.4 mm mesh), after which the filter was weighed to estimate the DW of the algae. Dominant algal species were identified by examination in a light microscope at $100 \times$ magnification. Since the dominant filamentous brown algae Ectocarpus sp. and green algae Ulva sp. grow both as epiphytes and as free-floating mats, and because filaments easily break when frozen, a clear distinction between epiphytes and free-floating macroalgae could not be made. Therefore, the data on algae were pooled to represent total algal biomass in the analyses. All animals associated with each Zostera sample were collected using a sieve (0.2 mm mesh). The crustaceans and gastropods were identified to species or family using a stereomicroscope and then counted and dried $\left(60^{\circ} \mathrm{C}\right.$, species separated) for at least $24 \mathrm{~h}$, and total ash-free dry weight (AFDW) was estimated after combustion in a muffle furnace at $450^{\circ} \mathrm{C}$ for at least $3 \mathrm{~h}$. We used AFDW instead of DW to measure grazer biomass because different invertebrate species contain different amounts of organic tissue in relation to their total body weight.

To investigate differences between the Zostera beds in the 3 regions, we performed 1-way ANOVA followed by planned post hoc comparisons (Sokal \& Rohlf 1995). The ANOVA was carried out using the sites (5 levels) as the independent variable and Zostera biomass (g DW), Zostera shoot density, the biomass of filamentous algae ( $g$ DW), and the biomass of all potential grazers on filamentous algae ( $g$ AFWD) as dependent variables. As the literature is not clear regarding the feeding preferences of the invertebrates that inhabit eelgrass beds, we performed a second assessment of the biomass of algal grazers based on the results of the isotope analyses (see below). The planned post hoc analyses were then carried out to

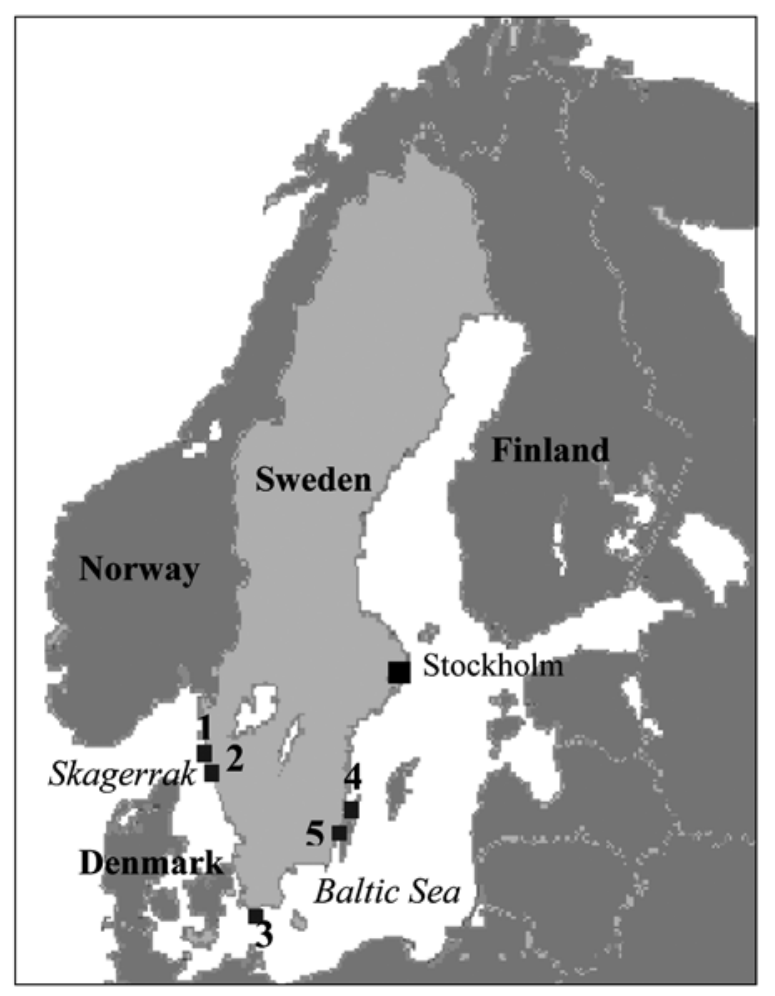

Fig. 1. Study locations along the west (Sites 1 and 2), south (Site 3), and southeast (Sites 4 and 5) coasts of Sweden 
compare the samples from the west coast (Sites 1 and 2) with those from the south coast (Site 3) and the southeast coast (Sites 4 and 5) and to compare the south coast samples with those from the southeast coast. Correction for multiple comparisons was achieved using the Dunn-Sidák method. Data on shoot density, filamentous algae, and grazer biomass were square root transformed to make them homogeneous and normally distributed (determined by Levene's test and Kolmo-gorov-Smirnov test, respectively). To assess the relationship between the different estimates of grazer biomass and filamentous algae, and between the biomass of algae and Zostera biomass and shoot density in each Zostera bed, mean values were calculated for each variable at each of the 5 sites, and the relationships were tested using Pearson's correlation analysis and SPSS 14.0.

Stable-isotope analyses. To explore the trophic structure in Swedish eelgrass communities and to test whether grazer species consumed both algae and Zostera leaves, stable-isotope analyses of nitrogen and carbon on plant and animals in eelgrass beds from each region were analyzed. Stable-isotope studies have been carried out to investigate trophic interactions in seagrass communities (Davenport \& Bax 2002, Smit et al. 2006, Tomas et al. 2006), but there appear to be few of this type of study in temperate eelgrass beds (Kharlamenko et al. 2001, Fredriksen et al. 2004). The technique is straightforward and comparatively simple (Peterson \& Fry 1987, Post 2002). Organisms often exhibit characteristic isotopic signatures. The isotope distributions of $\delta^{15} \mathrm{~N}$ have been successfully used to define an organism's trophic position since $\delta^{15} \mathrm{~N}$ values typically increase during each trophic transfer (Peterson \& Fry 1987, France 1994). The enrichment of 3.4\% (1\% SD; Post 2002) as a mean increase between trophic levels has been globally accepted and used recently (Sherwood \& Rose 2005, Moens et al. 2005, Nyström et al. 2006), but considerable variations in the enrichment in $\delta^{15} \mathrm{~N}$ between diet and consumer have been reported for marine invertebrates (McCutchan et al. 2003, Vanderklift \& Ponsard 2003, Svensson et al. 2007).

In contrast, the carbon isotope value changes little as carbon moves through the food web and is therefore used to evaluate the sources of carbon for an organism. Organisms usually have $\delta^{13} \mathrm{C}$ signatures of \pm 0.4 (1.3\% SD; Post 2002) or up to $1 \%$ o higher values than their food (DeNiro \& Epstein 1978, Peterson \& Fry 1987).

The nitrogen and carbon isotope signatures were studied and analyzed within 3 Zostera beds (1 from each region) on the west coast (Site 2), south coast (Site 3), and the southeast coast (Site 4). Zostera leaves and the dominating species of filamentous algae and fauna were collected using the trap design described above. Detritus was picked out from sediment samples. Due to low abundance of algae in the south and southeast coast beds, the algae species were not separated before analysis. Additional fish specimens for stableisotope analysis of dominant smaller fish species on the west coast that were not efficiently sampled with the trap method were kindly donated from simultaneously occurring fish investigations in the Zostera bed at Site 2 (Pihl et al. 2006). Despite extra fishing efforts on the southeast coast, no predatory fish such as perch or sticklebacks were caught or seen (SCUBA diving) at the study sites.

Isotope signatures were analyzed in all dominant macroinvertebrates and fish encountered in the present study. Average-sized individuals of the amphipods, isopods, and gastropods from each Zostera bed were used for the analyses. Muscle tissues from the fishes and the shrimp were dissected and then homogenized to a fine powder before analyses (Peterson \& Fry 1987, Post 2002). Entire individuals of large amphipods and isopods were homogenized before analysis. For invertebrates $<3 \mathrm{~mm}$ in body length, several individuals were pooled within species, and not homogenized, to obtain enough biomass to carry out the analysis. For the smallest gastropods (e.g. Hydrobia spp.) enough tissue could not be gained to carry out the analysis. Body sizes of the analyzed individuals are described as total length (TL), or in carapace length (CL), or width (CW).

The isotope analysis was carried out using a continuous flow isotope ratio mass spectrometer PDZ Europa 20-20 isotope analyser. All isotope values are reported in the $\delta$ notation where $\delta^{13} \mathrm{C}$ or $\delta^{15} \mathrm{~N}=\left(\mathrm{R}_{\text {sample }} /\right.$ $\left.\mathrm{R}_{\text {standard }}-1\right) \times 1000$. $\mathrm{R}$ is the ratio of ${ }^{15} \mathrm{~N}:{ }^{14} \mathrm{~N}$ or ${ }^{13} \mathrm{C}:{ }^{12} \mathrm{C}$, and as standard, Pee Dee Belemnite is used for carbon, and atmospheric nitrogen is used for nitrogen. Glycine was used as the internal standard. The precision of the measurement was $0.1 \%$ for carbon and $0.2 \%$ for nitrogen. The isotope signatures in the present study are given as mean delta notations in per mille (\%o).

One of the main difficulties in using stable isotopes to assess trophic transfers within coastal food webs is the large number of potential food sources. Recently, mixing models based on stable isotopes have been proposed to derive the relative contributions of each food source. To estimate proportions of food sources using the isotopic signatures of the grazing herbivore species we used linear mixing model IsoSource, Version 1.3.1 (available at www.epa.gov/wed/pages/models.htm) designed by Phillips \& Gregg (2001, 2003). For the crustacean grazers (Gammarus locusta, Idotea baltica, and Microdeutopus gryllotalpa) and the gastropod grazers (Rissoa spp., Littorina spp., Radix baltica, and Theodoxus fluviatilis) we used $\delta^{13} \mathrm{C}$ signatures to estimate the relative contribution (\%) of Zostera, filamen- 
tous algae, and detritus. As the trophic fraction of $\delta^{13} \mathrm{C}$ is relatively small (about $\pm 1 \%$ of values of their food; DeNiro \& Epstein 1978, Peterson \& Fry 1987) and because we lack information about the number of trophic levels between basal resources and consumers, we did not correct consumer $\delta^{13} \mathrm{C}$ values for trophic fractionation. The nitrogen isotope signatures of the crustacean and gastropod grazers did not reveal clear enrichment compared to any of the predictable food sources. Due to the lack of knowledge of true nitrogen enrichment of the species, we only included the carbon isotope signatures in the model. We carried out independent $t$-tests to test for significant differences in isotope signature between species where $\delta^{15} \mathrm{~N}$ signatures were overlapping. Source increment was set at $1 \%$ in the model, and tolerance was initially set at $0.1 \%$ (Phillips \& Gregg 2003).

In addition, we estimated the relative contribution (\%) of food sources (e.g. crustaceans, gastropods, and filamentous algae) for the omnivore grass shrimp Palaemon adspersus and P. elegans, since their functional roles in the different beds are unclear and since the results revealed high abundance of the shrimp in the south coast bed. The nitrogen isotopic signature was enriched in P. adspersus and P. elegans compared to the food sources.

The $\delta^{15} \mathrm{~N}$ and $\delta^{13} \mathrm{C}$ signatures were studied combined in the model. For $\delta^{15} \mathrm{~N}$ we employed the enrichment of 3.4\% with each trophic level (Post 2002). Source increment was set at $1 \%$. Tolerance was initially set at $0.1 \%$ (Phillips \& Gregg 2003). If mixture isotope values were out of bounds (i.e. outside the polygon delineated by the food web end members; Phillips \& Gregg 2001), we incrementally increased the tolerance value to a maximum of $0.5 \%$. Descriptive statistics are provided as a way to describe the entire distribution of feasible solutions. To avoid misrepresenting the results, mean and the distribution of feasible solutions (1st to 99th percentile) are reported (Phillips \& Gregg 2003). The $\delta^{15} \mathrm{~N}$ and $\delta^{13} \mathrm{C}$ values of higher trophic levels (e.g. fish) were only analysed graphically.

\section{RESULTS}

\section{Zostera community characteristics}

The characteristics of the sediment and Zostera differed between the 2 west coast sites and the sites in the Baltic (south and southeast coast). Compared to the sediment samples from the Baltic, those from the west coast had higher LOI values (Table 1), which indicates low exposure but not necessarily high anthropogenic enrichment. In addition, we found a maximum value of $25 \%$ for LOI at west coast Site 2, which means that the level today is about the same as the value of $20 \%$ measured in the same area in 1980 to 1982 (Baden \& Pihl 1984).

The biomass of Zostera differed significantly among the 5 sites, but the difference was too small to be detected by the planned post hoc test among regions (Table 2, Fig. 2). The Zostera plants in the west coast beds had longer and wider leaves, but lower shoot density, compared to those at the Baltic sites, and thus the biomass was similar for the regions (Table 1). The shoot density was significantly higher in the south coast than in southeast coast beds, and in turn was significantly higher in the southeast beds than in those off the west coast (Table 2, Fig. 2).

Table 1. Geographical position, salinity, sampling depth, sediment organic content (loss on ignition), and Zostera leaf length for the different study sites

\begin{tabular}{|c|c|c|c|c|c|c|c|c|c|}
\hline \multirow[t]{2}{*}{ Site } & \multirow[t]{2}{*}{ Position } & \multirow{2}{*}{$\begin{array}{l}\text { Depth } \\
\text { (m) }\end{array}$} & \multirow{2}{*}{$\begin{array}{l}\text { Salinity } \\
\text { (psu) }\end{array}$} & \multicolumn{3}{|c|}{ Organic content (\%) } & \multicolumn{3}{|c|}{ Leaf length $(\mathrm{cm})$} \\
\hline & & & & Mean & $\mathrm{SD}$ & $\mathrm{N}$ & Mean & $\mathrm{SD}$ & $\mathrm{N}$ \\
\hline \multicolumn{10}{|c|}{ West coast } \\
\hline 1 & $\begin{array}{c}58^{\circ} 14^{\prime} 32.7^{\prime \prime} \mathrm{N} \\
11^{\circ} 24^{\prime} 43.0^{\prime \prime} \mathrm{E}\end{array}$ & $1.5-2$ & 18.2 & 10.4 & 3.0 & 3 & 69.3 & 5.1 & 18 \\
\hline 2 & $\begin{array}{l}58^{\circ} 15^{\prime} 48.9^{\prime \prime} \mathrm{N} \\
11^{\circ} 29^{\prime} 45.6^{\prime \prime} \mathrm{E}\end{array}$ & $1.5-3.5$ & 20.1 & 25.2 & 4.8 & 5 & 89.8 & 29.3 & 18 \\
\hline \multicolumn{10}{|c|}{ South coast } \\
\hline 3 & $\begin{array}{c}55^{\circ} 23^{\prime} 16.3^{\prime \prime} \mathrm{N} \\
13^{\circ} 00^{\prime} 37.1^{\prime \prime} \mathrm{E}\end{array}$ & $1.3-3.2$ & 7.9 & 0.7 & 0.3 & 4 & 35.5 & 7.5 & 18 \\
\hline \multicolumn{10}{|c|}{ Southeast coast } \\
\hline 4 & $\begin{array}{c}56^{\circ} 42^{\prime} 09.6^{\prime \prime} \mathrm{N} \\
16^{\circ} 28^{\prime} 36.1^{\prime \prime} \mathrm{E}\end{array}$ & $2.5-3$ & 5.8 & 0.7 & 0.2 & 4 & 44.3 & 8.2 & 18 \\
\hline 5 & $\begin{array}{l}56^{\circ} 36^{\prime} 31.8^{\prime \prime} \mathrm{N}, \\
16^{\circ} 24^{\prime} 51.9^{\prime \prime} \mathrm{E}\end{array}$ & $2.0-4.0$ & 5.9 & 3.0 & 0.7 & 5 & 63.6 & 7.0 & 18 \\
\hline
\end{tabular}


Table 2. One-way ANOVA using the sites (5 levels) as the independent variable and the following as dependent variables: Zostera shoot density and biomass (g DW), filamentous algae (g DW), all potential grazers (g AFDW) of filamentous algae (Grazer 1), and specific grazer species (g AFDW) selected based on the results of isotope analysis (Grazer 2). Planned post hoc tests were subsequently carried out to compare the west coast Zostera beds (Sites 1 and 2) with the south coast (Site 3) and southeast coast (Sites 4 and 5) beds, and to compare the south coast bed with the southeast coast beds. Correction for multiple comparisons was done using the Dunn-Sidák method. Significant $(\mathrm{p}<0.05)$ and non-significant $(\mathrm{p}>0.05)$ results are indicated by ${ }^{*}$ and NS, respectively

\begin{tabular}{|c|c|c|c|c|c|}
\hline Source of variation & SS & df & MS & $F_{\mathrm{S}}$ & \\
\hline \multicolumn{6}{|l|}{ Zostera biomass } \\
\hline Sites & 56330.11 & 4 & 13506.62 & 3.64 & ${ }^{*}$ \\
\hline West vs. south & 20981.04 & 1 & 20981.04 & 5.89 & NS \\
\hline West vs. southeast & 22679.84 & 1 & 22679.84 & 6.37 & NS \\
\hline South vs. southeast & 194.41 & 1 & 194.41 & 0.05 & NS \\
\hline Within & 74798.43 & 21 & 3561.83 & & \\
\hline \multicolumn{6}{|c|}{ Zostera shoot density } \\
\hline Sites & 982.34 & 4 & 245.58 & 11.79 & * \\
\hline West vs. south & 738.85 & 1 & 738.85 & 35.48 & * \\
\hline West vs. southeast & 274.07 & 1 & 274.07 & 13.16 & * \\
\hline South vs. southeast & 186.72 & 1 & 186.72 & 8.97 & * \\
\hline Within & 416.47 & 20 & 20.82 & & \\
\hline \multicolumn{6}{|c|}{ Filamentous macroalgae } \\
\hline Sites & 20.80 & 4 & 5.20 & 21.43 & ${ }^{*}$ \\
\hline West vs. south & 17.10 & 1 & 17.10 & 70.38 & * \\
\hline West vs. southeast & 11.36 & 1 & 11.36 & 46.73 & * \\
\hline South vs. southeast & 1.62 & 1 & 1.62 & 6.66 & NS \\
\hline Within & 4.61 & 19 & 0.24 & & \\
\hline \multicolumn{6}{|l|}{ Grazer 1 biomass } \\
\hline Sites & 3.58 & 4 & 0.89 & 1.75 & NS \\
\hline West vs. south & 2.54 & 1 & 2.54 & 4.97 & NS \\
\hline West vs. southeast & 0.04 & 1 & 0.04 & 4.97 & NS \\
\hline South vs. southeast & 2.54 & 1 & 2.54 & 0.09 & NS \\
\hline Within & 12.76 & 25 & 0.51 & & \\
\hline \multicolumn{6}{|l|}{ Grazer 2 biomass } \\
\hline Sites & 7.89 & 4 & 1.97 & 6.00 & * \\
\hline West vs. south & 6.89 & 1 & 6.89 & 20.96 & $*$ \\
\hline West vs. southeast & 3.22 & 1 & 3.22 & 9.80 & * \\
\hline South vs. southeast & 1.35 & 1 & 1.35 & 4.09 & NS \\
\hline Within & 7.34 & 25 & 0.33 & & \\
\hline
\end{tabular}

The total biomass of filamentous algae was significantly greater in the 2 west coast beds than in the beds in the other regions (Table 2, Fig. 2). At the west coast sites, there was a predominance of filamentous brown algae (Ectocarpus spp. $40 \%$ ), filamentous green algae (Ulva spp. $28 \%$ and Cladophora sp. 6\%), and filamentous red algae (Ceramium sp. $21 \%$ and Polysiphonia spp. $6 \%$ ), and the fouling also included sediment tubes from the amphipods Erichtonius difformis and Corophium insidiosum. The algae noted in both the south and the southeast beds were Ceramium sp., Polysiphonia spp., Cladophora sp., Ectocarpus spp., and Brogniartella sp. The red algae dominated, but it was not possible to estimate the relative dominance of different taxa due to the overall low abundance of algae.

The invertebrate communities associated with the Zostera beds differed between the study areas. At the west coast sites, the predominant crustaceans were the amphipods Erichtonius difformis, Corophium insidosium, Microdeutopus gryllotalpa, and Gammarus locusta (TL 0.5 to $3 \mathrm{~mm}$ ), and the omnivorous grass shrimp Palaemon elegans and P. adspersus (TL 26 to $48 \mathrm{~mm})$, and the most numerous gastropods were Rissoa spp. and Hydrobia spp. In the south coast beds, Palaemon spp. predominated together with G. locusta and the isopod Idotea baltica, which were larger there than at the west coast sites (avg. TL $6.6 \pm 3.9$ and $9.2 \pm$ $5.1 \mathrm{~mm} \pm \mathrm{SD}$, respectively). The gastropods were primarily Theodoxus fluviatilis, Radix baltica, and Hydrobia ventrosa. The invertebrate community in the southeast beds was dominated by very large $G$. locusta and I. baltica (avg. TL $10.5 \pm 5.8$ and $10.7 \pm 4.1 \mathrm{~mm}$, respectively), and there were also large numbers of the gastropods T. fluviatilis and $H$. ventrosa. A complete list of the composition, abundance, and biomasses of the invertebrate species is presented in Table 3.

Based on information in the literature, we included Microdeutopus gryllotalpa, Gammarus locusta, Idotea

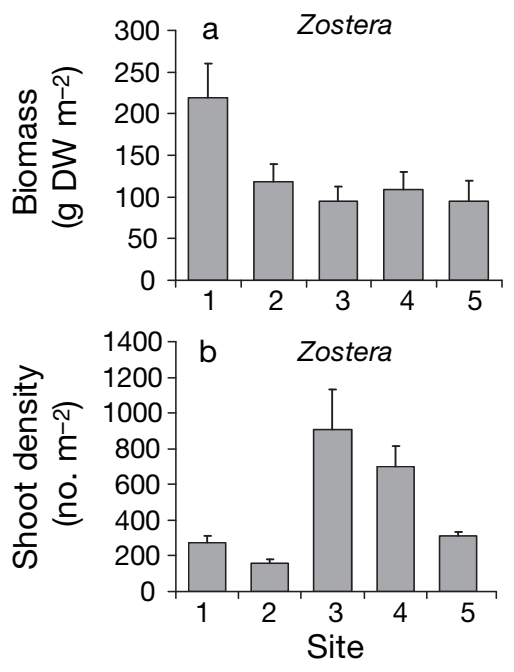

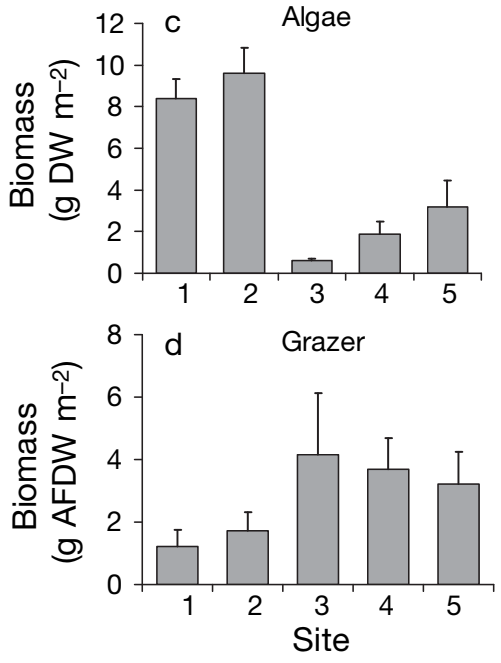

Fig. 2. Mean \pm SE (a) Zostera biomass, (b) Zostera shoot density, (c) biomass of filamentous algae, and (d) biomass of all potential grazers $( \pm \mathrm{SE})$ in the 5 Zostera beds off the Swedish west coast (Sites 1 and 2), south coast (Site 3), and southeast coast (Sites 4 and 5) 


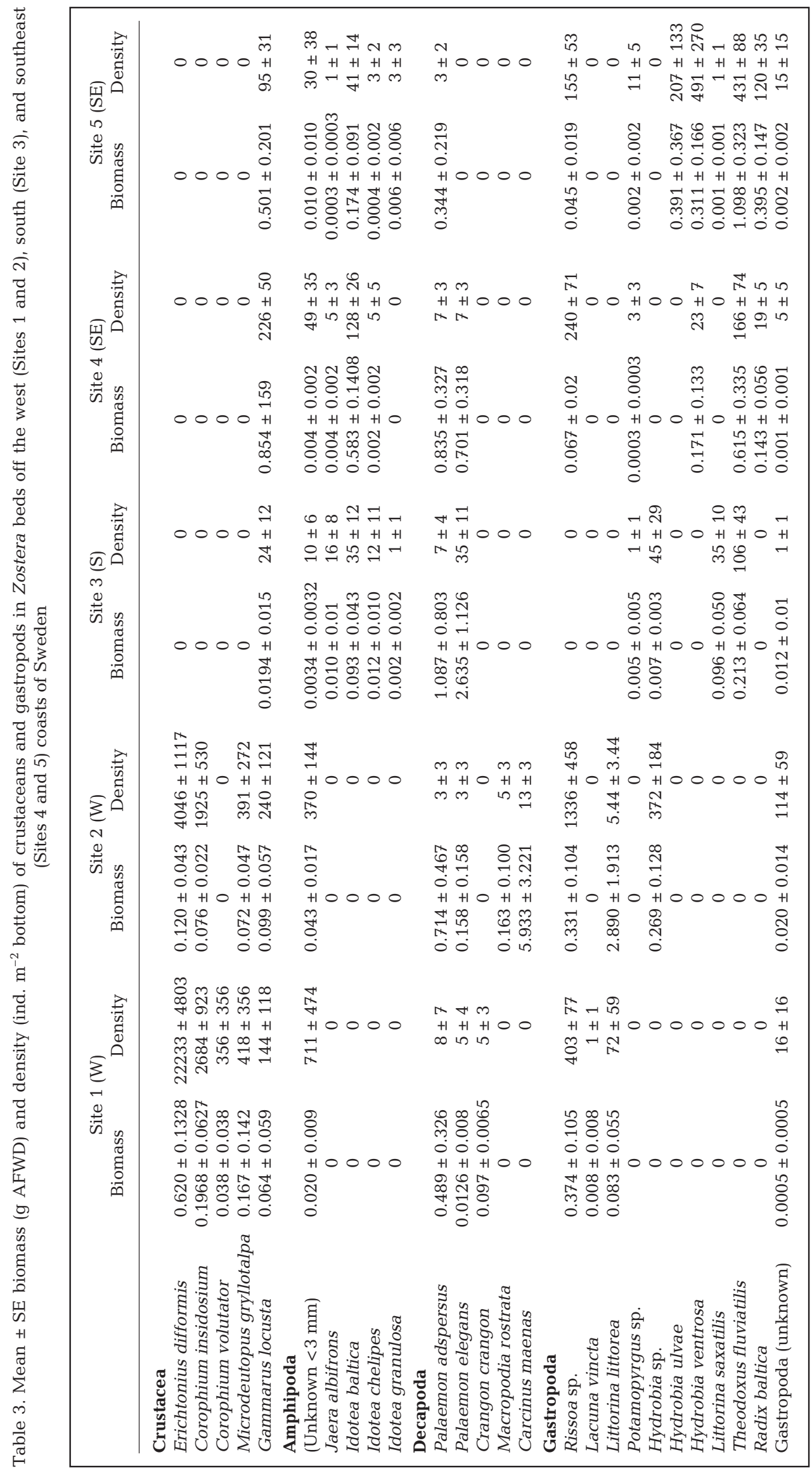




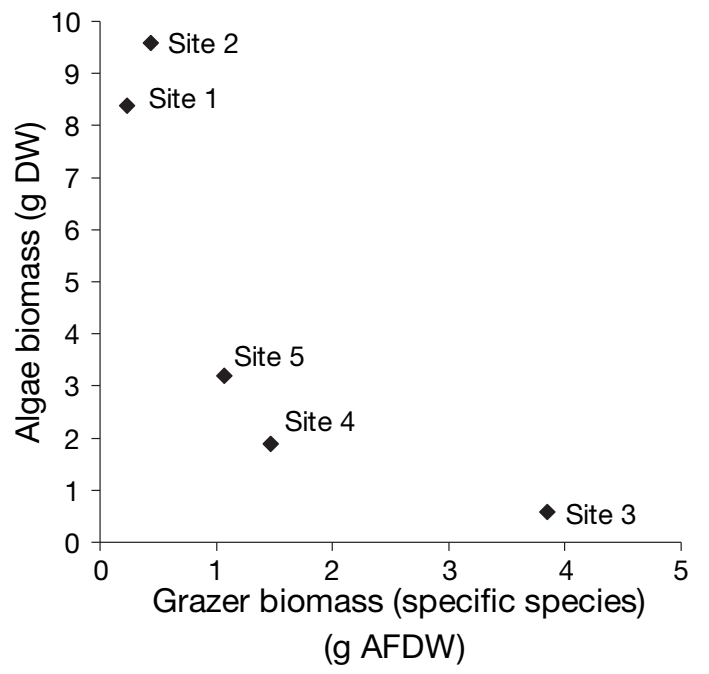

Fig. 3. Correlation between filamentous algae and biomass of grazers (g AFDW) selected based on the results of isotope analysis

spp., Palaemon spp., Rissoa spp., Littorina spp., Hydrobia spp., Radix baltica, Theodoxus fluviatilis, and Potamopyrgus sp. in the analysis of potential algal mesograzers. The small, tube-building amphipods Erichtonius difformis and Corophium insidiosum were not included, since these species are suspension- or deposit-feeders (Rasmussen 1973, Nair \& Anger 1979) and hence have no negative impact on macroalgal growth (Moksnes et al. 2008). The biomass of potential algal grazers did not differ significantly between the 5 Zostera beds (Table 2, Fig. 2). However, according to the results of the isotope and mixing function analyses (see below), the omnivorous grass shrimp Palaemon spp. fed mainly on filamentous algae in the south coast bed, whereas algae constituted a less important part of their diet at the west and southeast coast sites. Therefore, in the second analysis of mesograzer biomass,
Palaemon spp. were not included as algal grazers in the analyses of samples from the west and southeast regions. For the same reason, the gastropods from the west coast, and $T$. fluviatilis from the south and southeast coasts, were excluded from the analysis. The biomass values for the selected algal grazers differed markedly between the Zostera beds, with significantly lower biomasses of mesograzers at the west coast sites compared to the south and southeast coast sites, which did not differ from each other (Table 2).

Testing for relationships between the mean biomasses of filamentous algae and mesograzers at the 5 study sites, we found a significant negative correlation between algae and all potential mesograzers (Pearson's correlation $\mathrm{p}<0.05, \mathrm{n}=5, \mathrm{r}^{2}=0.94$ ). A similar trend was detected between algae and selected grazers when we tested biomass values derived from the isotope analyses, but the correlation was not significant ( $\mathrm{p}=0.10, \mathrm{n}=5, \mathrm{r}^{2}=0.65$; Fig. 3 ). However, that correlation showed a non-random distribution of residuals, indicating a log-linear relationship, and thus a log transformation of the algal biomass data improved the random distribution of residuals, giving a significant negative correlation $\left(\mathrm{p}=0.01, \mathrm{r}^{2}=0.93\right)$.

\section{Fauna community and stable isotope analysis}

The stable isotope analyses revealed complex trophic interactions in which filamentous algae appeared to constitute the most important food base in the Zostera communities in all 3 study regions. Few species seemed to utilize detritus as food, and only 2 of the gastropod species appeared to assimilate Zostera. The results also implied that large amphipods and isopods were the most important grazers on filamentous algae, and those crustaceans were in turn consumed by both shrimp and fish. However, the trophic

Table 4. Proportional contribution of $\delta^{13} \mathrm{C}$ in food sources of the most predominant crustacean and gastropod grazers in each study region, as given by the IsoSource linear mixing model (Phillips \& Gregg 2003). Values (\%) are means and distribution of feasible solutions (1st to 99th percentile)

\begin{tabular}{|llccc|}
\hline Study region & Consumer & Zostera marina & $\begin{array}{c}\text { Food source } \\
\text { filamentous algae }\end{array}$ \\
\hline West coast & Gammarus locusta & $8(0$ to 16$)$ & $83(81$ to 86$)$ & $9(0$ to 19$)$ \\
& Microdeutopus gryllotalpa & $5(0$ to 11$)$ & $89(87$ to 90$)$ & $6(0$ to 13$)$ \\
& Rissoa sp. & $80(63$ to 94$)$ & $3(0$ to 6$)$ & $17(0$ to 36$)$ \\
South coast & Littorina littorea & $35(0$ to 69$)$ & $23(14$ to 31$)$ & $43(0$ to 85$)$ \\
& Gammarus locusta & $3(0$ to 7$)$ & $92(90$ to 94$)$ & $5(0$ to 10$)$ \\
Southeast coast & $23(0$ to 45$)$ & $46(36$ to 55$)$ & $32(0$ to 63$)$ \\
& Idotea baltica & $0(0$ to 2$)$ & $98(95$ to 100$)$ & $2(0$ to 5$)$ \\
& Gammarus locusta & $30(13$ to 47$)$ & $27(0$ to 53$)$ & $43(0$ to 86$)$ \\
& Idotea baltica & $98(96$ to 99$)$ & $1(0$ to 2$)$ & $2(0$ to 4$)$ \\
& Theodoxus fluviatilis & $9(0$ to 18$)$ & $68(51$ to 83$)$ & $24(0$ to 48$)$ \\
\hline
\end{tabular}



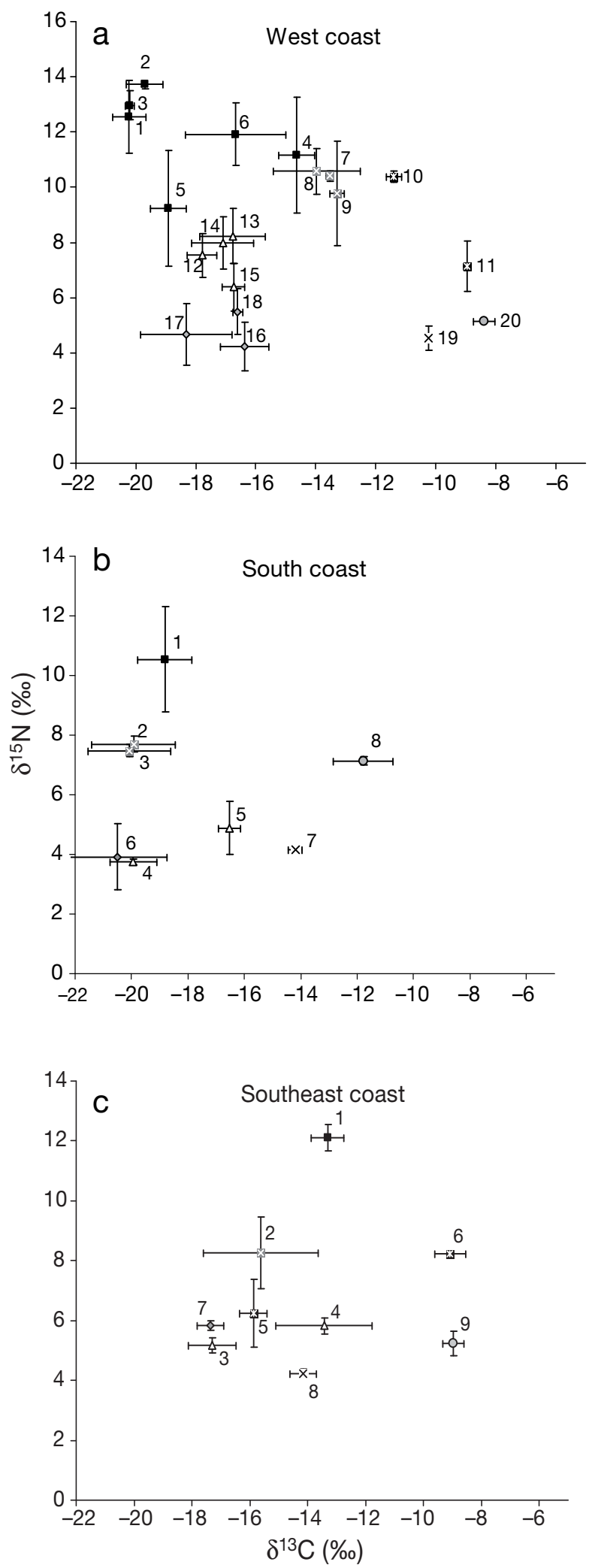

Fig. 4. Mean $\pm \mathrm{SD}$ of $\delta^{15} \mathrm{~N}$ and $\delta^{13} \mathrm{C}$ signatures of a number of species associated with Zostera beds off the (a) west, (b) south, and (c) southeast coasts of Sweden. See Table 5 for key to species for each panel role of omnivorous grass shrimp appeared to differ between the regions.

At the west coast sites, the linear mixing model analysis of $\delta^{13} \mathrm{C}$ suggested that the amphipod grazers Gammarus locusta and Microdeutopus gryllotalpa mainly assimilated filamentous algae (Table 4), which is also supported by the finding of significantly higher $\delta^{15} \mathrm{~N}$ signatures for the amphipods than for the algae (Fig. 4a, Tables 5 \& 6). In contrast, the mixing model results indicated that Zostera constituted the main food source for the dominant gastropods of the genus Rissoa (Table 4). Rissoa spp. showed an average $\delta^{15} \mathrm{~N}$ enrichment of $2 \%$ compared to Zostera (Fig. 4 a, Table 5). The mixing model also disclosed that amphipods and gas-

Table 5. Each species and total length (TL), carapace length (CL), or carapace width (CW) for the data points in Fig. 4

\begin{tabular}{|c|c|c|c|}
\hline No & Species & Measurement (mm) & $\mathrm{n}$ \\
\hline \multicolumn{4}{|c|}{ West coast } \\
\hline 1 & Gadus morhua & $\mathrm{TL} \sim 110$ & 5 \\
\hline 2 & Syngnathus typhle & $\mathrm{TL} \sim 150$ & 1 \\
\hline 3 & Gobiusculus flavescens & $\mathrm{TL} \sim 40$ & 4 \\
\hline 4 & Gobius niger & TL 50 to 60 & 4 \\
\hline 5 & Gobius niqer & TL 92 to 98 & 2 \\
\hline 6 & Gasterosteus aculeatus & TL $\sim 50$ & 4 \\
\hline 7 & Carcinus maenas & CW 30 to 40 & 2 \\
\hline 8 & Palaemon elegans & CL 3 to 10 , TL 26 to 48 & 3 \\
\hline 9 & Palaemon adspersus & CL 3 to 10, TL 26 to 48 & 2 \\
\hline 10 & Littorina littorea & TL 20 & 2 \\
\hline 11 & Rissoa sp. & $\mathrm{TL} \sim 4$ & 5 \\
\hline 12 & Microdeuoptus gryllotalpa & TL 0.5 to 3 & 2 \\
\hline 13 & Erichtonius difformis & TL 0.5 to 3 & 6 \\
\hline 14 & Corophium insidiosum & TL 0.5 to 3 & 3 \\
\hline 15 & Gammarus locusta & $\mathrm{TL} \sim 5$ & 7 \\
\hline 16 & Ectocarpales & & 4 \\
\hline 17 & Ulva sp. & & 4 \\
\hline 18 & Polysiphonia sp. & & 4 \\
\hline 19 & Detritus & & 2 \\
\hline 20 & Zostera marina & & 2 \\
\hline \multicolumn{4}{|c|}{ South coast } \\
\hline 1 & Spinachia spinachia & TL 70 to 100 & 3 \\
\hline 2 & Palaemon elegans & $\mathrm{CL}>7, \mathrm{TL}>39$ & 2 \\
\hline 3 & Palaemon adspersus & $\mathrm{CL}>7, \mathrm{TL}>39$ & 2 \\
\hline 4 & Gammarus locusta & TL $\sim 7$ & 2 \\
\hline 5 & Idotea baltica & TL $\sim 9$ & 2 \\
\hline 6 & Filamentous algae & & 6 \\
\hline 7 & Detritus & & 2 \\
\hline 8 & Zostera marina & & 2 \\
\hline \multicolumn{4}{|c|}{ Southeast coast } \\
\hline 1 & Gobius niger & $\mathrm{TL} \sim 100$ & 1 \\
\hline 2 & Palaemon adspersus & CL 3 to 10 , TL 26 to 48 & 4 \\
\hline 3 & Gammarus locusta & $\mathrm{TL} \sim 10$ & 5 \\
\hline 4 & Idotea baltica & $\mathrm{TL} \sim 10$ & 6 \\
\hline 5 & Radix baltica & TL 5 to 10 & 3 \\
\hline 6 & Theodoxus fluventalis & $\mathrm{TL} \sim 4$ & 2 \\
\hline 7 & Filamentous algae & & 3 \\
\hline 8 & Detritus & & 3 \\
\hline 9 & Zostera marina & & 4 \\
\hline
\end{tabular}


tropods, in turn, were the main food of the grass shrimp Palaemon elegans and P. adspersus, and the shrimp had mean $\delta^{15} \mathrm{~N}$ signatures between 1.6 and $4.2 \%$ higher than those noted for the amphipods and gastropods (Fig. 4a, Table 5). The $\delta^{15} \mathrm{~N}$ signatures of the 2 shrimp species did not differ significantly (Table 6). The fish Gobius niger also appeared to be an important predator of amphipods, because it had a significantly higher $\delta^{15} \mathrm{~N}$ signature than the amphipods did (Fig. 4a, Tables 5 \& 6). The 2 different size classes of $G$. niger that were analyzed (TL 50 to 60 and 92 to $98 \mathrm{~mm}$ ) had similar $\delta^{15} \mathrm{~N}$ signatures, suggesting that both groups fed on the same trophic level, but they had different carbon isotope signatures (Table 6) and thus probably also different diets. Furthermore, the smaller G. niger had a nitrogen isotope signature closer to that of the grass shrimp (Fig. 4a, Table 5), indicating a higher proportion of gastropods in the diet. In the west coast beds, the fish Gadus morhua, Gobiusculus flavescens, Syngnathus typhle, and Gasterosteus aculeatus had the highest mean $\delta^{15} \mathrm{~N}$ isotope signatures, which might demonstrate predation on a higher trophic level.

At the south coast site, the proportional contribution of $\delta^{13} \mathrm{C}$ revealed that filamentous algae was the most important food source for Gammarus locusta (Table 4), although $\delta^{15} \mathrm{~N}$ signature was not significantly higher for G. locusta than for the algae (Fig. 4b, Tables 5 \& 6). We also found that the $\delta^{15} \mathrm{~N}$ signature of the isopod Idotea baltica did not differ significantly from that of $G$. locusta; even though the mixing model suggested that filamentous algae represent an important part of the diets of those species, it seems that they also consume detritus and Zostera (Table 4). The mean $\delta^{15} \mathrm{~N}$ signatures of G. locusta and I. baltica were $2.6 \%$ to $4.0 \%$ lower than those of Palaemon elegans and P. adspersus, indicating that the shrimp consumed these grazers (Fig. 4b, Tables 5 \& 7). However, according to the mixing model, filamentous algae constituted the most important food source for $P$. elegans and $P$. adspersus in the south coast bed (but not in the west and southeast beds; Table 7), since the shrimp had mean $\delta^{15} \mathrm{~N}$ signatures 3.8 and $3.6 \%$ higher than the signature in the algae (Fig. 4b, Table 5). No significant difference in $\delta^{15} \mathrm{~N}$ was found between $P$. elegans and $P$. adspersus (Table 7). Fish of the species Spinachia spinachia had $\delta^{15} \mathrm{~N}$ signatures 2.8 and $3.1 \%$ higher than the values for $P$. adspersus and $P$. elegans, respectively, indicating that $S$. spinachia preyed on those shrimp in the south coast bed.

The mixing model analysis of $\delta^{13} \mathrm{C}$ at the southeast sites suggests that filamentous algae constituted the most important food source for both Gammarus locusta and the gastropod Radix baltica (Table 4), although the $\delta^{15} \mathrm{~N}$ signatures of those animal species could not reveal any enrichment compared to the algae (Fig. 4c,
Table 5). The $\delta^{15} \mathrm{~N}$ signature of the isopod Idotea baltica differed significantly from that of G. locusta (Table 6), and the mixing model indicated that the food consisted of algae, detritus, and Zostera, although in highly varying proportions (Table 4 ). Theodoxus fluviatilis showed $3.0 \%$ enrichment of $\delta^{15} \mathrm{~N}$ compared to Zostera in the southeast coast beds, and the mixing model findings suggest Zostera is the most important food source for that gastropod (Table 4). The mixing model results for the southeast sites also indicated that Palaemon adspersus consumed mainly G. locusta and I. baltica, since those 2 species had significantly lower $\delta^{15} \mathrm{~N}$ signatures (3.1 and $2.4 \%$, respectively) than the shrimp did (Fig. 4c, Tables 5 \& 7). The fish Gobius niger had the highest $\delta^{15} \mathrm{~N}$ isotope signature, and it was $3.9 \%$ higher than the $\delta^{15} \mathrm{~N}$ signature of $P$. adspersus, indicating that the former species may be a predator on the latter in the southeast coast beds.

\section{DISCUSSION}

The present study assessed structural aspects and trophic relationships in Zostera communities in 3 regions that are affected in different ways by eutrophication-related overgrowth of macroalgae. The results revealed striking dissimilarities in the communities with regard to the biomass of fast-growing filamentous algae and the biomass and size structure of the grazers. There was a significant negative correlation between the mean biomasses of the filamentous algae and the grazers at each site. This observation is not consistent with the 'production ceiling hypothesis', which suggests that plant production controls the biomass of motile epifauna (Edgar \& Aoki 1993, Edgar \& Klumpp 2003), but instead it indicates that the algal biomass is controlled by grazers, which in turn may also be controlled by top-down processes. Although we measured the standing stock of algal biomass and not the production of algae in the present study, previous observations showing high biomass of filamentous algae in eelgrass beds off the Swedish west coast do suggest that algal production is higher in that region than in the eelgrass systems along the Swedish south and southeast coasts (S. P. Baden unpubl. data). However, our data do not allow us to adequately assess the effect of grazer biomass on algal biomass, because the presence of filamentous algae is also determined by exposure to prevailing winds, which may have a greater impact on the south and southeast beds. That assumption is supported by the low organic content we found in the sediment in the south and southeast beds.

The dramatic differences between the 3 regions with regard to biomass and mean size of the large mesograzers Gammarus spp. and Idotea spp. are consistent 
Table 6. Results of independent $t$-test used to analyze differences in $\delta^{15} \mathrm{~N}$ between species (see Table 3 for species names in full). -: species not found in the area

\begin{tabular}{|c|c|c|c|c|c|c|c|c|c|}
\hline \multirow[t]{2}{*}{ Species } & \multicolumn{3}{|c|}{ West coast } & \multicolumn{3}{|c|}{ South coast } & \multicolumn{3}{|c|}{ Southeast coast } \\
\hline & $\mathrm{p}$ & $\mathrm{df}$ & $t$ & $\mathrm{p}$ & df & $t$ & $\mathrm{p}$ & df & $t$ \\
\hline R. baltica vs. algae & - & - & - & - & - & - & $>0.05$ & 3 & 0.46 \\
\hline I. baltica vs. algae & - & - & - & $>0.05$ & 8 & 1.36 & $>0.05$ & 4 & 0.09 \\
\hline M. gryllotapla vs. algae & $<0.05$ & 18 & 2.00 & - & - & - & - & - & - \\
\hline G. Locusta vs. algae & $<0.05$ & 23 & 2.36 & $>0.05$ & 6 & 0.29 & $<0.05$ & 3 & 3.20 \\
\hline G. locusta vs. I. baltica & - & - & - & $>0.05$ & 4 & 1.98 & $<0.05$ & 9 & 3.11 \\
\hline P. elegans vs. algae & $<0.05$ & 20 & 7.50 & $<0.05$ & 8 & 6.25 & - & - & - \\
\hline$P$. adspersus vs. algae & $<0.05$ & 19 & 6.73 & $<0.05$ & 8 & 6.67 & 0.056 & 4 & 2.67 \\
\hline Palaemon sp. vs. I. baltica & - & - & - & $<0.05$ & 10 & 10.38 & $<0.05$ & 6 & 3.94 \\
\hline Palaemon sp. vs. G. locusta & $<0.05$ & 12 & 14.52 & $<0.05$ & 8 & 24.69 & $<0.05$ & 5 & 4.25 \\
\hline Palaemon sp. vs. E. difformis & $<0.05$ & 11 & 5.25 & - & - & - & - & - & - \\
\hline Palaemon sp. vs. M. gryllotalpa & $<0.05$ & 7 & 6.82 & - & - & - & - & - & - \\
\hline Palaemon sp. vs. C. insidosium & $<0.05$ & 8 & 6.35 & - & - & - & - & - & - \\
\hline$P$. adspersus vs. $R$. baltica & - & - & - & - & - & - & 0.07 & 5 & 2.25 \\
\hline P. elegans vs. $P$. adspersus & $>0.05$ & 4 & 0.19 & $>0.05$ & 6 & 1.68 & - & - & - \\
\hline $\begin{array}{l}\text { G. niger (TL } 50 \text { to } 60 \mathrm{~mm} \text { vs. } \\
\text { G. niger (TL } 92 \text { to } 98 \mathrm{~mm} \text { ) }\end{array}$ & $>0.05$ & 9 & 1.90 & - & - & - & - & - & - \\
\hline
\end{tabular}

Table 7. Proportional contribution of food sources (using $\delta^{15} \mathrm{~N}$ and $\delta^{13} \mathrm{C}$ combined) for Palaemon elegans and $P$. adspersus, as given by the IsoSource linear mixing model (Phillips \& Gregg 2003). Values (\%) are mean and distribution of feasible solutions (1st to 99th percentile). Source increment was set at $1 \%$. Tolerance was $0.1 \%$ with the following exceptions: $0.2 \%$ for $P$. elegans in the south coast bed and $0.5 \%$ for $P$. adspersus in the southeast coast beds; P. elegans was not found at the southeast sites

\begin{tabular}{|c|c|c|}
\hline Consumer & Food source & t contribution to diet \\
\hline \multicolumn{3}{|l|}{ West coast } \\
\hline \multirow[t]{6}{*}{ Palaemon elegans } & Gammarus locusta & $10(0-32)$ \\
\hline & Microdeutopus gryllotalpa & $15(0-47)$ \\
\hline & Erichtonius difformis & $16(0-38)$ \\
\hline & Corophium insidiosum & $15(0-43)$ \\
\hline & Rissoa sp. & $39(0-42)$ \\
\hline & Filamentous algae & $5(0-16)$ \\
\hline \multirow[t]{6}{*}{ Palaemon adspersus } & Gammarus locusta & $9(0-30)$ \\
\hline & Microdeutopus gryllotalpa & $5(0-18)$ \\
\hline & Erichtonius difformis & $4(0-12)$ \\
\hline & Corophium insidiosum & $4(0-14)$ \\
\hline & Rissoa sp. & $48(46-50)$ \\
\hline & Filamentous algae & $31(20-39)$ \\
\hline \multicolumn{3}{|l|}{ South coast } \\
\hline \multirow[t]{3}{*}{ Palaemon elegans } & Gammarus locusta & $2(0-4)$ \\
\hline & Idotea baltica & $19(19-19)$ \\
\hline & Filamentous algae & $79(77-81)$ \\
\hline \multirow[t]{3}{*}{ Palaemon adspersus } & Gammarus locusta & $8(0-22)$ \\
\hline & Idotea baltica & $10(7-13)$ \\
\hline & Filamentous algae & $82(67-91)$ \\
\hline \multicolumn{3}{|l|}{ Southeast coast } \\
\hline \multirow[t]{5}{*}{ Palaemon adspersus } & Gammarus locusta & $73(72-76)$ \\
\hline & Idotea baltica & $26(23-28)$ \\
\hline & Theodoxus fluviatilis & $0.1(0-1)$ \\
\hline & Radix baltica & $0.3(0-1)$ \\
\hline & Filamentous algae & $0.5(0-2)$ \\
\hline
\end{tabular}

with top-down control of such species and expected high, intermediate, and low abundance of small predators at the west, south, and southeast coast sites, respectively. Size-specific fish predation on amphipods has been found to cause a shift in the population size structure towards smaller individuals in many aquatic systems (Edgar \& Aoki 1993, Blumenshine et al. 2000), including the eelgrass beds along the Swedish west coast (Moksnes et al. 2008). There is little information available at present regarding the abundance of small fish predators at the Baltic sites we studied. However, recent cage experiments carried out by Moksnes et al. (2008) using the same sites as we did have suggested that predation pressure on mesograzers is markedly higher in the 2 west coast Zostera beds than in the 2 southeast beds. Moksnes et al. (2008) observed that $G$. locusta can reach a large size and very high biomass in the absence of local predators, and hence that species can control the growth of filamentous green algae, even during periods of nutrient enrichment. However, those investigators also noted that local predators reduced the mean size and abundance of gammarids to very low levels, resulting in increased algal 
growth. Similar cage experiments at the southeast sites did not reveal any effect of predators (S. P. Baden unpubl. data). On the west coast the fish species Gobius niger and Gasterosteus aculeatus are among the most abundant primary predators (Pihl et al. 2006), and the isotope assimilation data suggest that these species prey on the amphipod assemblage.

The mixing model analysis in the present study indicated that Gammarus locusta is an important grazer on filamentous algae. Algae also constituted the main source of food for the amphipod Microdeutopus gryllotalpa, whereas the isopod Idotea baltica and the gastropod Radix baltica appeared to feed only partly on algae, which agrees with other results in the literature (Duffy et al. 2001, Jormalainen et al. 2001, Goecker \& Kåll 2003, Andersson 2005). The nitrogen isotope signatures of the grazers did not reveal clear enrichment compared to algae. However, recent studies have also detected considerable variation in nitrogen enrichment by marine invertebrates (McCutchan et al. 2003, Svensson et al. 2007), and consumers feeding mainly on detritus tend to exhibit lower $\delta^{15} \mathrm{~N}$ discrimination than do carnivores or herbivores (Vanderklift \& Ponsard 2003). This may also apply to I. baltica in the beds at our south and southeast sites. Only 2 small gastropods (Rissoa sp. and Theodoxus fluviatilis) had carbon and nitrogen signatures indicating assimilation of Zostera as their main source of food. It is plausible that Zostera epidermis is ingested by animals as they browse on the film of microalgae and bacteria on the surface of the leaves (Fredriksen et al. 2004).

Our isotope analyses of the omnivorous grass shrimp suggest that these species are more carnivorous in the beds off the west and southeast coasts than at the site off the south coast, and thus they may play different trophic roles in the 3 regions. This deduction is supported by a recent study of Zostera beds along the Swedish west coast (Persson et al. 2008), in which it was found that Palaemon elegans preferred to feed on small gammarids rather than algae, resulting in a positive net effect on algal growth. However, if the gammarids were more than $5 \mathrm{~mm}$ in length, $P$. elegans shifted towards consuming algae. The low abundance of small amphipod prey in our south coast Zostera bed may explain why $P$. elegans mainly assimilated algae. Analysis of the stomach contents of the south coast shrimp confirmed that the animals had chiefly ingested filamentous algae ( $T$. Jephson unpubl. data).

In conclusion, this study identified Gammarus locusta, Microdeutopus gryllotalpa, and Radix baltica as the most important grazers of macroalgae, and Idotea sp. and Palaemon spp. (on the south coast) probably have a negative impact on algal growth as well. G. locusta and Idotea baltica showed greater biomass and mean sizes in the Baltic Sea beds (south and south- east coasts) compared to the west coast beds, where $G$. locusta individuals were $<5 \mathrm{~mm}$ and Idotea spp. were missing, even though we found the highest algal biomass at those sites. Therefore, it can be expected that the grazing pressure on algae will be lower in the west coast Zostera beds than in the south and southeast coast beds. Lower grazing pressure on algae at the west coast sites may be the result of top-down control of grazers due to a trophic cascade effect. In short, that means that overfishing and a decrease in large predators may have increased the density of intermediate predators, which in turn has lowered the biomass of algal mesograzers, and such a reduction in grazing control has then allowed the filamentous algae to flourish during periods of nutrient pollution. Also, the isotope signatures indicate that Zostera was used only to a limited extent as a source of energy by the predominant invertebrates.

Acknowledgements. We are grateful to P. Ödman for checking the language, K. Tryman for help with species identification, and K. Olsson for assistance with the isotope analyses. Thanks to J. Stadmark, L. Svensson, and M. Svensson for help with the field work. This research was funded by grants from the Swedish Environmental Protection Agency (SEPA contract no. I-58-03 to P.O.M. and I-55-03 to S.P.B.; awarded to the national project Marine Biodiversity Patterns and Processes, MARBIPP) and the Swedish Research Council for Environment, Agricultural Sciences and Spatial Planning (FORMAS contract no. 21.5/2003-0213 to S.P.B.).

\section{LITERATURE CITED}

Andersson J, Dahl J, Johansson A, Karås P, Nilsson J, Sandström O, Svensson A (2000) Recruitment failure and decreasing fish stocks in the coastal areas of Kalmarsund. The Council of Fisheries in Sweden, Stockholm

Andersson PM, Andersson LS (2006) Long-term trends in the sea surrounding Sweden. Part one-nutrients. Report 2006-34, Swedish Meteorological and Hydrological Institute, Stockholm

Andersson S (2005) Grazing capacity on ephemeral algae and intra-trophic interactions of the amphipod Gammarus locusta. Masters thesis, Göteborg University

Baden SP (1990) The cryptofauna of Zostera marina (L.): abundance, biomass and population dynamics. Neth J Sea Res 27:81-92

Baden SP, Pihl L (1984) Abundance, biomass and production of mobile epibenthic fauna in Zostera marina meadows, western Sweden. Ophelia 23:65-90

> Baden SP, Gullström M, Lundén B, Pihl L, Rosenberg R (2003) Vanishing Seagrass (Zostera marina, L.) in Swedish coastal waters. Ambio 32:374-377

Blumenshine SC, Lodge DM, Hodgson JR (2000) Gradient of fish predation alters body size distribution of lake benthos. Ecology 81:374-386

> Davenport SR, Bax NJ (2002) A trophic study of a marine ecosystem off southeastern Australia using stable isotopes of carbon and nitrogen. Can J Fish Aquat Sci 59:514-530

> DeNiro MJ, Epstein S (1978) Influence of diet on the distribution of carbon isotopes in animals. Geochim Cosmochim 
Acta 42:495-506

Duarte P (1995) A mechanistic model of the effects of light and temperature on algal primary productivity. Ecol Model 82:151-160

Duffy JE, Harvilicz AM (2001) Species-specific impacts of grazing amphipods in an eelgrass-bed community. Mar Ecol Prog Ser 223:201-211

Duffy JE, Macdonald KS, Rhode JM, Parker DJ (2001) Grazer diversity, functional redundancy and productivity in seagrass beds: an experimental test. Ecology 82:2417-2434

Edgar GJ, Aoki M (1993) Resource limitation and fish predation; their importance to mobile epifauna associated with Japanese Sargassum. Oecologia 95:122-133

- Edgar GJ, Klumpp DW (2003) Consistences over regional scales in assemblages of mobile epifauna associated with natural and artificial plants of different shape. Aquat Bot 75:275-291

France RL (1994) Nitrogen isotopic composition of marine and freshwater invertebrates. Mar Ecol Prog Ser 115:205-207

Fredriksen S, Christie H, Boström C (2004) Deterioration of eelgrass (Zostera marina L.) through destructive grazing by the gastropod Rissoa membranacea (J. Adams). Sarsia 89:218-222

Goecker M, Kåll S (2003) Grazing preferences of marine isopods and amphipods on three prominent algal species of the Baltic Sea. J Sea Res 50:309-314

> Hauxwell J, Cebrian J, Valiela I (2003) Eelgrass Zostera marina loss in temperate estuaries: relationship to landderived nitrogen loads and effect of light limitation imposed by algae. Mar Ecol Prog Ser 247:59-73

Heck KL Jr, Pennock JR, Valentine JF, Coen LD, Sklenar SA (2000) Effects of nutrient enrichment and small predator density on seagrass ecosystems: an experimental assessment. Limnol Oceanogr 45:1041-1057

Howarth RW, Saney DP, Butler TJ, Marino R (2000) Climatic control on eutrophication of the Hudson River estuary. Ecosystems 3:210-215

Hughes AR, Bando KJ, Rodriguez LF, Williams SL (2004) Relative effects of grazers and nutrients on seagrasses: a meta-analysis approach. Mar Ecol Prog Ser 282:87-99

Jackson JBC, Kirby MX, Berger WH, Bjorndal KA and others (2001) Historical overfishing and the recent collapse of coastal ecosystems. Science 293:629-637

> Jormalainen V, Honkanen T, Heikkilä N (2001) Feeding preferences and performance of a marine isopod on seaweed hosts: cost of habitat specialization. Mar Ecol Prog Ser 220: 219-230

Kharlamenko VI, Kiyashko SI, Imbs AB, Vyshkvartzev DI (2001) Identification of food sources of invertebrates from the seagrass Zostera marina community using carbon and sulfur stable isotope ratio and fatty acid analyses. Mar Ecol Prog Ser 220:103-117

Lagenfelt I, Svedäng H (1999) Fisk och fiske i Västerhavets och Öresunds kustområden. Fiskeriverkets rapport, The Council of Fisheries in Sweden, Stockholm, p 1-51

Lundgren F (2004) Epifauna i ålgräsängar-test av typiska arter i ett Natura 2000-habitat, Report 127, Toxicon, Landskrona, p 1-22

Lundgren F, Olsson P, Sjölin A, Nylander W (2006) Sydkustens Vattenvårdsförbund; Undersökninar längs sydkusten. Årsrapport. Annual report. The water protection agency investigation of the Swedish South coast, Trelleborg, p 1-59

> McCutchan JH, Lewis WM, Kendall C, McGrath C (2003) Variation in trophic shift for stable isotope ratios of carbon, nitrogen, and sulfur. Oikos 102:378-390

Moens T, Bouillon S, Gallucci F (2005) Dual stable isotope abundances unravel trophic position of estuarine nematodes. J Mar Biol Assoc UK 85:1401-1407

Moksnes PO, Gullström M, Tryman K, Baden S (2008) Trophic cascades in a temperate seagrass community. Oikos 117: 763-777

- Myers RA, Worm B (2003) Rapid worldwide depletion of predatory fish communities. Nature 423:280-283

Nair K, Anger K (1979) Life cycle of Corophium insidiosum, Crustacea, Amphipoda in laboratory culture. Helgol Wiss Meeresunters 32:279-294

Nilsson J, Andersson A, Karås P, Sandström O (2004) Recruitment failure and decreasing catches of Perch (Perca fluviatilis) in the coastal waters of southeast Sweden. Boreal Environ Res 9:295-306

Norkko A, Bonsdorff E (1996) Population responses of coastal zoobenthos to stress induced by drifting algal mats. Mar Ecol Prog Ser 140:141-151

Nyström P, Stenroth P, Holmqvist N, Berglund O, Larsson P, Granéli W (2006) Crayfish in lakes and streams: individual and population responses to predation, productivity and substratum availability. Freshw Biol 51:2096-2113

Orth RJ, Van Montfrans J (1984) Epiphyte seagrass relationships with an emphasis on the role of micro grazing a review. Aquat Bot 18:43-70

Persson M, Andersson S, Baden S, Moksnes PO (2008) Trophic role of the omnivorous grass shrimp Palaemon elegans in a Swedish eelgrass system. Mar Ecol Prog Ser (in press)

Peterson BJ, Fry B (1987) Stable isotopes in ecosystem studies. Annu Rev Ecol Syst 18:293-320

Phillips DL, Gregg JW (2001) Uncertainty in source partitioning using stable isotopes. Oecologia 127:171-179

Phillips DL, Gregg JW (2003) Source partitioning using stable isotopes: coping with too many sources. Oecologia 136: 261-269

Pihl L, Svensson A, Moksnes PO, Wennhage H (1999) Distribution of green algal mats throughout shallow soft bottoms of the Swedish Skagerrak archipelago in relation to nutrient sources and wave exposure. J Sea Res 41:281-294

Pihl L, Baden S, Kautsky N, Rönnbäck P, Söderqvist T, Troell M, Wennhage H (2006) Shift in fish assemblage structure due to loss of seagrass Zostera marina habitats in Sweden. Estuar Coast Shelf Sci 67:123-132

Polte P, Schanz A, Asmus H (2005) The contribution of seagrass beds (Zostera noltii) to the function of tidial flats as a juvenile habitat for dominant mobile epibenthos in the Wadden Sea. Mar Biol 147:813-822

Post DM (2002) Using stable isotopes to estimate trophic position: models, methods and assumptions. Ecology 83: 703-718

Rasmussen E (1973) Systematics and ecology of the Isefjord marine fauna (Denmark). Ophelia 11:1-507

Rosenberg R, Elmgren R, Fleischer S, Jonsson P, Persson G, Dahlin H (1990) Marine eutrophication case studies in Sweden. Ambio 19:102-108

Sherwood GD, Rose GA (2005) Stable isotope analysis of some representative fish and invertebrates of the Newfoundland and Labrador continental shelf food web. Estuar Coast Shelf Sci 63:537-549

Short FT, Wyllie-Echeverria S (1996) Natural and humaninduced disturbance of seagrasses. Environ Conserv 23: $17-27$

> Smit AJ, Brearley A, Hyndes GA, Lavery PS, Walker DI (2006) $\delta^{15} \mathrm{~N}$ and $\delta^{13} \mathrm{C}$ analysis of Posidonia sinuosa seagrass bed. Aquat Bot 84:277-282

Sokal R, Rohlf FJ (1995) Biometry. WH Freeman, New York Svedäng H (2003) The inshore demersal fish community on 
the Swedish Skagerrak coast: regulation by recruitment from offshore sources. J Mar Sci 60:23-31

Svedäng H, Bardon G (2003) Spatial and temporal aspects of the decline in cod (Gadus morhua) abundance in the Kattegatt and eastern Skagerrak. J Mar Sci 60:32-37

Svensson CJ, Hyndes GA, Lavery PS (2007) Food web analysis in two permanently open temperate estuaries: consequences of saltmarsh loss? Mar Environ Res 64: 286-304

Tomas F, Alvarez-Cascos D, Turon X, Romero J (2006) Differential element assimilation by sea urchins Paracentrotus lividus in seagrass beds: implications for trophic interactions. Mar Ecol Prog Ser 306:125-131

Valentine J, Duffy JE (2005) The central role of grazing in sea-

Editorial responsibility: Kenneth Heck,

Dauphin Island, Alabama, USA grass ecology. In: Larkum AWD, Orth RJ, Duarte CM (eds) Seagrasses: biology, ecology and conservation. Springer, New York, p 463-501

Valentine JF, Heck KL Jr (2001) The role of leaf nitrogen content in determining turtlegrass (Thalassia testudinum) grazing by a generalized herbivore in the northeastern Gulf of Mexico. J Exp Mar Biol Ecol 258:65-86

Valiela I, McClelland J, Hauxwell J, Behr PJ, Hersh D, Foreman K (1997) Macroalgal blooms in shallow estuaries: controls and ecophysiological and ecosystem consequences. Limnol Oceanogr 42:1105-1118

Vanderklift MA, Ponsard S (2003) Sources of variation in consumer-diet $\delta^{15} \mathrm{~N}$ enrichment: a meta-analysis. Oecologia 136:169-182

Submitted: March 11, 2007; Accepted: July 11, 2008 Proofs received from author(s): October 3, 2008 